\title{
A Preliminary Research to Develop A Customized Set of Vocabulary Size Test
}

\author{
Laurentia Sumarni \\ ELESP - Sanata Dharma University \\ laurentia.sumarni@gmail.com
}

\begin{abstract}
This is a preliminary research to investigate useful words to function effectively in academic contexts, vocabulary size, the first-year students' word list, and the steps to design the customized set of entrylevel vocabulary size test. This research was a library research. To find out the ELESP students' current vocabulary size, a vocabulary size test designed by Paul Nation was administered. The results show that useful words were (1) high-frequency words containing 2,000 word families, (2) academic words specified in the Academic Word List (Coxhead:2000), (3) technical words, (4) low-frequency words. The result of the administration of Nation's Vocabulary Size Test shows that the students' scores range between 33 and 96 words, with the mean score of 66. It means that the students' vocabulary size ranges between 3,300 and 9,600 word families. The average students' vocabulary size was 6,600 word families, which imply that most ELESP students are ready to read texts containing $88.7 \%$ word coverage. In order to increase their vocabulary size by 10,000 or more, they need to learn technical words and low-frequency words of a specialized subject area. Using Nation's specifications for making the test, some procedures of test design are: Sampling the words for the items, Making the Stem, Writing the choices, The Order of the items in the Test, Piloting, Administering the Test. The decisions on curriculum, materials and teaching strategies should be based on the results of vocabulary size to gain optimum learning outcome.
\end{abstract}

Keywords: entry level vocabulary size test, high-frequency words, low-frequency level words

\section{INTRODUCTION}

It is undeniable that vocabulary in language acquisition plays a very important role. For successful communication, vocabulary is very crucial and indispensable. In English language learning and teaching, vocabulary is the currency without which communication and meaning-making are impossible. In the Indonesian context, where English is a foreign language, a clear schoolbased standard of vocabulary size should be established as a guidance in curriculum, syllabus, and material development.

Ironically, in English language teaching, vocabulary is not considered important. This can be seen from the very little attention and consideration of vocabulary learning in the curriculum. It is assumed that vocabulary learning is integrated in the course subjects (implicit / incidental learning) and thus explicit or deliberate vocabulary learning is deemed unnecessary. Before performing the macro skills i.e. listening, speaking, reading and writing, vocabulary is the capital which enables students to understand, express, comprehend and write their ideas. In university level, students' academic success is always measured by means of written and spoken assessments, in which they show their knowledge of a particular topic by the use of specialized vocabulary.

Research on vocabulary size in other countries where English is a foreign language shows that a foreign language learner at the high school level in Taiwan was required to learn 6,600 words. The Japanese university students are required to learn 10,000 words, while the Russian university students must learn 15,000 words. In addition, the vocabulary size of the Dutch students is 10,000 words (Allen 1983). According to the 1984 English 
curriculum, a senior high school graduates are expected to master 4,000 words.

\section{$\mathrm{PBI}$ (ELESP-English Language}

Education Study Program) does not have an entry-level vocabulary test to decide which level students are at the beginning of their programs. A standard vocabulary size test is not available to determine the placement of new students, because students are admitted to the program based on their final high school mark in the English subject. In addition, decisions on curriculum, syllabus and material development are still based on common sense, instead of research-based. In response to this, an entry-level vocabulary test to measure $\mathrm{PBI}$ students' vocabulary size is crucial and urgent to be conducted because the test can give a lot of important information regarding the current vocabulary size. In turn, this information can be used as the basis to revise curriculum, syllabus, lesson plans, materials, class activities and assessment. This information will also help to solve many problems regarding students' low written and oral performance. Teachers and students will know which words and how many words students need to learn to be able to function effectively in academic settings. The information obtained from the tests can also be used to decide the necessary action plans to address the problems.

Therefore, this research aims to investigate these questions:

1) Which words are useful to enable $P B I$ students to function effectively in academic contexts?

2) Using Nation's Vocabulary Size Test, what is the size of the first-year students' vocabulary?

3) How many words should the first-year students learn?

4) What are the steps to design the set of customized entry-level vocabulary size tests?

It is hoped that this research can open opportunities for further research on vocabulary testing to explore its contribution in English language teaching and learning. Research on vocabulary testing can contribute to the development of science and knowledge in Indonesia, especially in shedding the lights on English language teaching, curriculum revision, teaching strategies, material development and language testing.

\section{THEORETICAL REVIEW}

This section outlines the literatures on vocabulary in English language teaching, learning and assessment. It is important, first of all, to define vocabulary and underline its significance in English language teaching and learning. Lehr, Osborn, \& Hiebert (2004) cited in Read (2000) define vocabulary as words we use to communicate in spoken and written language. Receptive vocabulary refers to the words we understand through reading and listening, while productive vocabulary refers to words we use to communicate through writing and speaking (as quoted in Hanson and Padua, 2011)

Some prominent researchers have all agreed that vocabulary is crucial and indispensable element to create effective and successful communication in written and spoken contexts. Pikulski and Templeton (nd) state that "our ability to function in today's complex social and economic worlds is mightily affected by our language skills and word knowledge." Success in life thus largely depends on our word knowledge and our ability to use the knowledge. Ellis (1997) has shown that "vocabulary knowledge is indispensable to acquire grammar." Vocabulary is very crucial to understand spoken and written discourses and to express ideas orally as well as in writing. Coombe adds that "experts in the field of vocabulary development are in agreement that vocabulary is central to the language learning process, and as such, it is generally accepted that a focus on strengthening vocabulary is necessary at every stage of a learner's language development." Folse (2003) as cited in Coombe, states that "without syntax, meaning is hindered; but without vocabulary meaning is impossible".

In the English Language Education Study Program, the students are required to listen to spoken discourses, read written texts, speak up their ideas and write academic essays. In short, they have to be able to perform various communicative tasks in academic settings. The assessments are based on their spoken and written performance. 
Therefore, their ability to speak and write using specialized vocabulary is used to judge their overall English ability. To be able to cope with this challenge, how many words should a student have? A number of researchers have come up with vocabulary size. Hirsch and
Nation suggest that "to achieve pleasurable reading it is necessary for learners to have a vocabulary of around 5,000 words." Waring and Nation have investigated the vocabulary size and text coverage in written discourse.

Table 1. Vocabulary Size and Text Coverage of written discourse

\begin{tabular}{cc}
\hline $\begin{array}{c}\text { Vocabulary size in Lemmas } \\
\text { (stem words and inflected forms) }\end{array}$ & Text coverage \\
\hline 1,000 & $72.0 \%$ \\
2,000 & $79.7 \%$ \\
3,000 & $84.0 \%$ \\
4,000 & $86.8 \%$ \\
5,000 & $88.7 \%$ \\
6,000 & $89.9 \%$ \\
15,851 & $97.8 \%$ \\
\hline
\end{tabular}

Note: Adapted from Nation, P., and Waring, R. (1997). Vocabulary size, text coverage and word lists. In N. Schmitt \& M. McCarthy (Eds.), Vocabulary: Description, acquisition and pedagogy (p. 9). Cambridge: Cambridge University Press. Copyright year by the name of the copyright holder. Adpated with permission.

Around 2,000 words are needed to reach $80 \%$ coverage of a written text. However, students must strive to get at least $98 \%$ coverage. Nation (2006) suggests the vocabulary sizes needed to get $98 \%$ coverage (including proper nouns) of various kinds of texts. The vocabulary sizes and the number of word families are shown in the following table.

Table 2: Vocabulary sizes to get $98 \%$ coverage in various kinds of written texts.

\begin{tabular}{|l|l|l|}
\hline Texts & $98 \%$ coverage & Proper nouns \\
\hline Novels & 9,000 word families & $1-2 \%$ \\
\hline Newspapers & 8,000 word families & $5-6 \%$ \\
\hline Children's movies & 6,000 word families & $1.5 \%$ \\
\hline Spoken English & 7,000 word families & $1.3 \%$ \\
\hline
\end{tabular}

Nation says that 'the goal of around 8,000 word families is an important one for learners who wish to deal with a range of unsimplified spoken and written texts." In writing, Nation (2008) suggests that "a small number of words (around 2,000 to 3,000) can be used effectively to express an enormous number of ideas." Nation $(1990,1993,2001)$ further adds that "the critical importance of developing an adequate high-frequency vocabulary since learner's skill in using the language is heavily dependent on the number of words they know, particularly in the early stages of learning a foreign language, with around 3,000 word families being a crucial threshold." Hirsch and Nation (1992) argue that "in order to reach text comprehension, readers need to be familiar with $95 \%$ of the words in a text." This text coverage percentage is logical because "to cope well in English, a second language learner would need around 5,000 words and preferably 10,000 words" (Nation, 2004).

In addition, a foreign language or a second language learner with higher vocabulary size will be more successful in his / her learning. Francis and Kucera (1982) suggest that "the 2,000 most frequent word families of English make up $79.7 \%$ of the individual words in any English text, the 3,000 most frequent word families represent $84 \%$, the 4,000 most frequent word families make up about $86.7 \%$, and the 5,000 most frequent word families cover $88.6 \%$. A much better reading comprehension power is ensured if a reader knows the meanings of at least $90 \%$ of the words in a text." In line with that, Schmitt states that "the vocabulary in the 2,000-3,000 
frequency band provides additional material for spoken discourse, but additionally, knowledge of around 3,000 word families is the threshold that should allow learners to begin to read authentic texts. Most research indicates that knowledge of the most frequent 5,000 word families should provide enough vocabulary to enable learners to read authentic texts." In short, the researchers agree that the bigger vocabulary size, the better learners will understand spoken and written discourses.

Considering the importance of vocabulary size and knowledge to enable a foreign language learner to function effectively in academic settings, vocabulary testing is thus crucial to be implemented. Nation (2008:144) argues that "vocabulary testing can be used to work out what needs to be taught, to monitor and encourage learning, to place learners in the right class, to measure learners' achievement, to measure learners' vocabulary size and performance." He further adds that for research purposes, vocabulary testing can be used to "evaluate teaching and learning activities." Anderson and Freebody found that "vocabulary size is a good predictor of reading comprehension." Coady, Magott, Hubbard,
Graney and Mokhtari (1993) also found that vocabulary is "an important factor for obtaining fluency in speech."

To measure vocabulary levels, The Vocabulary Levels Test (Nation,1983) was developed to find where learners' vocabulary needed attention. It consists of five levels of tests, sampling vocabulary from the $2^{\text {nd }} 1,000$ word level, the $3^{\text {rd }} 1,000$-word level, the $5^{\text {th }}$ 1,000-word level, the $10^{\text {th }} 1,000$-word level and the Academic Word List. Each level contains 30 items. The high frequency words of English include the $1^{\text {st }} 1,000$-word level and the $2^{\text {nd }} 1,000$-word level.

The Productive Levels Test (Nation, 2008:38) will give an indication of learners' productive vocabulary. For example, their spoken productive vocabulary can be checked by doing the Same or different pair exercise with pictures based on the General Service List. The following table summarizes the purposes and features of vocabulary tests (Nation, 2008:145) which will be used as the guidelines in developing the multiple-level vocabulary assessment tools to measure the vocabulary size and knowledge of the students in the ELESP.

Table 3: Purposes and features of vocabulary tests (Nation, 2008:145)

\begin{tabular}{|c|c|c|c|c|}
\hline $\begin{array}{l}\text { Reason for } \\
\text { Testing }\end{array}$ & $\begin{array}{l}\text { Selection of words } \\
\text { to test }\end{array}$ & Test requirements & $\begin{array}{l}\text { Useful formats and existing } \\
\text { tests }\end{array}$ & $\begin{array}{l}\text { Degree of } \\
\text { Difficulty }\end{array}$ \\
\hline $\begin{array}{l}\text { Encourage } \\
\text { learning }\end{array}$ & $\begin{array}{l}\text { Choose from what } \\
\text { the learners have } \\
\text { been studying }\end{array}$ & $\begin{array}{l}\text { Easy to mark } \\
\text { Easy to mark } \\
\text { Learners are likely to be } \\
\text { successful }\end{array}$ & $\begin{array}{l}\text { Teacher labeling, matching, } \\
\text { completion, translation }\end{array}$ & Easy \\
\hline Placement & $\begin{array}{l}\text { Choose from a range } \\
\text { of vocabulary levels }\end{array}$ & $\begin{array}{l}\text { Good reliability and validity } \\
\text { Quick to mark } \\
\text { Easy to interpret } \\
\text { Cover a wide range of levels }\end{array}$ & $\begin{array}{l}\text { Vocabulary Levels Test } \\
\text { (monolingual or bilingual) } \\
\text { Dictation Levels Test } \\
\text { Yes/No test } \\
\text { Matching } \\
\text { Multiple-Choice } \\
\end{array}$ & $\begin{array}{l}\text { A range of } \\
\text { difficulty }\end{array}$ \\
\hline Diagnosis & $\begin{array}{l}\text { Choose from a range } \\
\text { of vocabulary levels }\end{array}$ & $\begin{array}{l}\text { Good reliability and validity } \\
\text { Provide a lot of information } \\
\text { Cover a wide range of levels }\end{array}$ & $\begin{array}{l}\text { Vocabulary Levels Test } \\
\text { Dictation Levels Test } \\
\text { EVST -- Yes/No test }\end{array}$ & $\begin{array}{l}\text { A range of } \\
\text { difficulty }\end{array}$ \\
\hline $\begin{array}{l}\text { Award a grade } \\
\text { (achievement) }\end{array}$ & $\begin{array}{l}\text { Choose from what } \\
\text { the learners have } \\
\text { been studying }\end{array}$ & $\begin{array}{l}\text { Good reliability and validity } \\
\text { Method of testing matches } \\
\text { the kind of learning required }\end{array}$ & $\begin{array}{l}\text { Translation } \\
\text { Matching } \\
\text { Multiple-Choice }\end{array}$ & $\begin{array}{l}\text { Easy to } \\
\text { moderate } \\
\text { difficulty }\end{array}$ \\
\hline $\begin{array}{l}\text { Evaluate a } \\
\text { learning activity }\end{array}$ & $\begin{array}{l}\text { Choose from what } \\
\text { the learners have } \\
\text { been studying in the } \\
\text { activity }\end{array}$ & $\begin{array}{l}\text { Each word is tested in two } \\
\text { or three ways at different } \\
\text { levels of sensitivity }\end{array}$ & $\begin{array}{l}\text { Form Recognition } \\
\text { Multiple-Choice } \\
\text { Translation } \\
\text { Interview }\end{array}$ & $\begin{array}{l}\text { A wide } \\
\text { range of } \\
\text { difficulty }\end{array}$ \\
\hline $\begin{array}{l}\text { Measure the } \\
\text { learners' } \\
\text { proficiency }\end{array}$ & $\begin{array}{l}\text { Choose from a range } \\
\text { of vocabulary levels }\end{array}$ & Good reliability and validity & $\begin{array}{l}\text { Lexical Frequency Profile } \\
\text { Vocabulary Size Test } \\
\text { Translation }\end{array}$ & \\
\hline
\end{tabular}


It is clear now why vocabulary assessments need to be carried out. Vocabulary assessment can help teachers to measure the effectiveness of their teaching and learning activities. The purpose of vocabulary assessment, according to Read
(2000:2), is to "monitor the learner's progress in vocabulary learning and to assess how adequate their vocabulary knowledge is to meet their communication needs." He identifies three dimensions of vocabulary assessment as shown in the following figure.

Figure 1: Dimensions of Vocabulary assessment (Read 2000:9)

\section{Discrete}

A measure of vocabulary

knowledge or use as an

independent construct

\section{Selective}

A measure in which specific vocabulary items are the focus of the assessment

\section{Context-independent}

A vocabulary measure in which the test-taker can produce the expected response without referring to any context

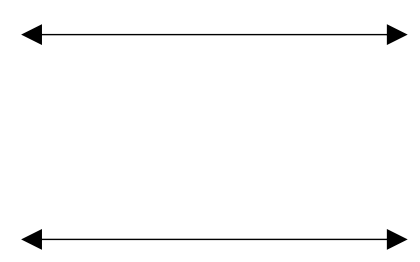

Embedded

A measure of vocabulary which forms part of the assessment of some other, larger construct

\section{Comprehensive}

A measure which takes account of the whole vocabulary content of the input material (reading/listening tasks or the test-taker's response (writing/speaking tasks)

\section{Context-dependent}

A vocabulary measure which assesses the test-taker's ability
According to Read, vocabulary size measures typically require a large sample of words that represent a defined frequency range, together with a simple response task to indicate whether each word is known or not. The Coxhead's Academic Word List will provide a great deal of words to be selected as test items. In addition, the General Service List developed by West (1953) which lists 2,000 high-frequency word families which account for a high percentage of the running words in any written or spoken English text still has "sound selection criteria of frequency, range, familiarity and pedagogical value" (Nation \& Waring, 1997; Read, 2000:227-28). This GSL still provides a solid foundation for work in vocabulary assessments.

\section{METHODOLOGY}

The method employed in this research was the library research aimed at finding the resources and references in the forms of books, articles, and journals which can support the researcher's opinion. It was conducted to obtain theories and concepts related to vocabulary tests to measure vocabulary size. The subjects of the research are references on vocabulary size tests. The detailed library research will focus on such activities as follows:

1) reading the Nation's Vocabulary Levels Test and Productive Vocabulary Levels Test, Meara's Yes/No Test, Martinez's Phrase-Test, Read's Word Associates Test, Coxhead's Academic Word List, the West's General Service List, and Thorndike's 30,000-word list. This also involves researching the internet resources on vocabulary tests.

2) choosing the type of tests to be tested to the first-semester students

3) Administering Nation's Vocabulary Size Test to 156 students of PBI

4) Analyzing the Results of the Test

5) Drawing Conclusions and Recommendations on the design of a customized entry-level vocabulary size test. 


\section{RESEARCH FINDINGS AND DISCUSSION}

This section will present the results of the research both qualitatively and quantitatively. This section will provide the research results to answer the four questions. The library research was conducted to answer the first question, i.e. which words are useful to enable PBI students to function effectively in academic contexts? Nation (2008:7) argues that "the most important group of words is the high frequency words of the language." In addition, these words are used very frequently both in formal and informal uses of the language, in spoken or written mode, in novels, conversations, academic texts, etc. Thus, the words that are useful to enable PBI students to function effectively in academic contexts are the high-frequency words consisting around 2,000 word families made up of 169 function words and 1831 content words.

In addition to the high-frequency words, students need to acquire academic words which are not included in the most frequent 1,000 or 2,000 words but which are used widely in the specialized area. Coxhead (as cited in Nation, 2008:9) found that there were 570 word families which she later called the Academic Word List. She also found that "the words from the AWL make up around $8.5 \%-10 \%$ of the running words in academic texts, that is, approximately one word in every ten comes from the AWL. Further, Nation asserts that the words in AWL are very important for learners who will use English for academic study either in upper secondary schools or in universities.

The third group of words that need to be acquired by the ELESP students was technical words. Since the subjects in ELESP deal mostly with linguistics, literature and education, students must be familiar with words related to those fields. According to Nation (2008:10), "technical words are clearly very important for anyone who specializes in a particular area." He further adds that "at least $20 \%$ of the running words in most technical texts are likely to be technical words" and "(technical words) probably range in size from around 1,000 words to 5,000 words depending on the subject area." So, the group of words that the ELESP students need to acquire is the words used in linguistics, literature and education fields which range up to 5,000 words.

Lastly, the ELESP students need to acquire the low-frequency words as well in order to function effectively in academic settings. The low-frequency words make up the biggest and most diverse group of words. They include (1) words that are not quite frequent or wide range enough to be high frequency words, (2) technical words from other areas, and (3) words that just occur rarely. According to Nation (2008:11), English probably has a low frequency vocabulary of around 20,000 word families. Students need to know these low-frequency words in order to understand conversations, to read newspapers and understand academic texts, although the time devoted to teach these low-frequency words may not be as much as that devoted to teach high-frequency words.

To answer the second question, a vocabulary size test designed by Nation and Beglar was administered to the ELESP 2013 students at the beginning of the program to find out the size of students' vocabulary. The test was chosen because it has fulfilled the criteria of a good test, namely reliable, valid, and practical. The test was given to 165 students of the ELESP, but 9 students did not take the test for various reasons, so only 156 tests were administered. Based on the test results, the mean score of the students' vocabulary size was 66 . To find out the vocabulary size, the score is multiplied by 100 . So, the mean score 66 suggests that the students' average vocabulary size was 6,600 words. Out of 156 students, the score ranges between 33 and 96 , which suggests that the students' lowest vocabulary size was 3,300 words and the highest vocabulary size was 9,600 words.

The median score was 65 and the mode was 58 which imply that half of the students scored between 65 and 96 . This means that more than $50 \%$ of the total students (78 people) already had a vocabulary size above 5,000 words. As stated in the 
literature review, most research indicates that knowledge of the most frequent 5,000 word families should provide enough vocabulary to enable learners to read authentic texts. From the results, it can be seen that actually most PBI students are lexically ready to read texts containing $88.7 \%$ text coverage. It means that with around 5,000 words, students are not familiar with $11.3 \%$, or around 11 words per 100-word text.

Nation's Vocabulary Size Test is a discrete, selective, relatively contextindependent vocabulary test presented in a multiple-choice format in which test-takers were required to select the best definition of each word from four choices. The test consists of 140 multiple-choice items representing 14,000 word families of English. Each 1,000 word family level is represented by 10 items. In order to get the total receptive vocabulary size, each student's total score needs to be multiplied by 100 . To see what words were tested, the test items will be listed as follows:

$1^{\text {st }} 1,000$ : see, time, period, figure, poor, drive, jump, shoe, standard, basis.

$2^{\text {nd }}$ 1,000: maintain, stone, upset, drawer, patience, nil, pub, circle, microphone, pro.

$3^{\text {rd }}$ 1,000: soldier, restore, jug, scrub, dinosaur, strap, pave, dash, rove, lonesome.

$4^{\text {th }} 1,000$ : compound, latter, candid, tummy, quiz, input, crab, vocabulary, remedy, allege.

$5^{\text {th }}$ 1,000: deficit, weep, nun, haunt, compost, cube, miniature, peel, fracture, bacterium. $6^{\text {th }} 1,000$ : devious, premier, butler, accessory, threshold, thesis, strangle, cavalier, malign, veer.

$7^{\text {th }}$ 1,000: olive, quilt, stealth, shudder, bristle, bloc, demography, gimmick, azalea, yoghurt.

$8^{\text {th }}$ 1,000: erratic, palette, null, kindergarten, eclipse, marrow, locust, authentic, cabaret, mumble.

$9^{\text {th }} 1,000$ : hallmark, puritan, monologue, weir, whim, perturb, regent, octopus, fen, lintel.

$10^{\text {th }} 1,000$ : awe, peasantry, egalitarian, mystique, upbeat, cranny, pigtail, crowbar, ruck, lectern.

$11^{\text {th }}$ 1,000: excrete, mussel, yoga, counterclaim, puma, pallor, aperitif, hutch, emir, hessian.

$12^{\text {th }} 1,000$ : haze, spleen, soliloquy, reptile, alum, refectory, caffeine, impale, coven, trill.

$13^{\text {th }} 1,000$ : ubiquitous, talon, rouble, jovial, communique, plankton, skylark, beagle, atoll, didactic.

$14^{\text {th }} 1,000$ : canonical, atop, marsupial, augur, bawdy, gauche, thesaurus, erythrocyte, cordillera, limpid.

The first five 1,000 were the highfrequency words and students were already familiar with these words. Consequently, they scored better in these three 1,000 levels. The test was graded based on the level of difficulty and the degree of frequency of the words based on the British National Corpus. The distribution of the total scores for each part can be seen in the following table.

Table 4: The students' total scores for each part of the test.

\begin{tabular}{|c|c|c|c|c|}
\hline Section of Test & $\begin{array}{c}\text { Students' Total } \\
\text { Scores }\end{array}$ & $\begin{array}{c}\text { Degree of } \\
\text { Answerability }\end{array}$ & & \\
\hline $1^{\text {st }} 1,000$ & 1337 & $86 \%$ & The highest & 1 \\
\hline $2^{\text {nd }} 1,000$ & 1103 & $71 \%$ & & 2 \\
\hline $3^{\text {rd }} 1,000$ & 1026 & $66 \%$ & & 3 \\
\hline $4^{\text {th }} 1,000$ & 997 & $64 \%$ & & 4 \\
\hline
\end{tabular}




\begin{tabular}{|c|c|c|c|c|}
\hline $5^{\text {th }} 1,000$ & 901 & $58 \%$ & & 5 \\
\hline $6^{\text {th }} 1,000$ & 643 & $41 \%$ & & 7 \\
\hline $7^{\text {th }} 1,000$ & 587 & $38 \%$ & & 8 \\
\hline $8^{\text {th }} 1,000$ & 860 & $55 \%$ & & 13 \\
\hline $9^{\text {th }} 1,000$ & 456 & $29 \%$ & & 9 \\
\hline $10^{\text {th }} 1,000$ & 525 & $34 \%$ & & 10 \\
\hline $11^{\text {th }} 1,000$ & 492 & $32 \%$ & The lowest & 14 \\
\hline $12^{\text {th }} 1,000$ & 481 & $31 \%$ & & 12 \\
\hline $13^{\text {th }} 1,000$ & 394 & $25 \%$ & & 11 \\
\hline $14^{\text {th }} 1,000$ & 489 & $31 \%$ & & \\
\hline
\end{tabular}

From the table, it can be seen that students' ability to answer the fifth to first 1,000 test items ranged between $64 \%-86 \%$. It means that students are familiar with the words. The low degree of answerability in the rest of the words in the test items shows that the words tested were not familiar. This rings true because the words were taken from the low-frequency words which occur in specific contexts and specific texts. The lowest degree of answerability was in the $13^{\text {th }} 1,000$. Only
$25 \%$ of the total 10 words could be answered, which means averagely only 2 or 3 numbers were answered correctly. It can be concluded that, in average, the 2013 ELESP students are already familiar with around 5,000 most frequent word families which cover $88.6 \%$ text coverage. The following table shows the relationship between the frequency level the vocabulary size score and what students need to do to increase their vocabulary size (Nation:2012).

Table 5.: The relationship between frequency level, vocabulary size and learning procedures.

\begin{tabular}{|l|l|l|}
\hline Level & $\mathbf{1 0 0 0}$ word family lists & Learning procedures \\
\hline High frequency & $1000-2000$ & $\begin{array}{l}\text { Reading graded readers } \\
\text { Deliberate teaching and } \\
\text { learning }\end{array}$ \\
\hline Mid-frequency & $3000-9000$ & $\begin{array}{l}\text { Reading mid-frequency } \\
\text { readers } \\
\text { Deliberate learning }\end{array}$ \\
\hline Low frequency & 10,000 on & $\begin{array}{l}\text { Wide reading } \\
\text { Specialised study of a } \\
\text { subject area }\end{array}$ \\
\hline
\end{tabular}

The result can be used to answer the third question, i.e. How many words should the first-year students learn? Since in average, they are already familiar with the 6,600 word families, which represent high-frequency words in English language, students are encouraged to acquire more technical words related to linguistics, literature and education.
In addition, they must also acquire lowfrequency words in order to understand texts in higher semesters. Thus, they would logically need to learn 7,500 - 9,000 word families in their first year. Based on table 5, students are now at the mid-frequency level, with vocabulary size ranging from $3,000-9,000$ word families. In order to increase their 
vocabulary size by 10,000 , they need to learn words deliberately and widely on technical words and low-frequency words of a specialized subject area.

Besides using the test results to measure the total receptive written vocabulary size for the ELESP students, the instructional purpose of the test administration was to use it as a reference in syllabus design, extensive reading, and vocabulary instruction. However, this vocabulary size test seems to underestimate the vocabulary size of the students who were not motivated to perform to the best of their ability. The administration of the test also opened wide opportunity for wild guessing. To obtain more valid data of the students' vocabulary size, this test should be followed up with another series of vocabulary size test, such as Bilingual Vocabulary Size Test, Vocabulary Levels Test, and Yes/No Test.

Some findings and experts' opinions will be presented in this section to answer the fourth question, i.e. What are the steps to design a customized set of entry-level vocabulary size tests? Here are the procedures of the vocabulary size test design adapted from Nation's Specification for making the test (Nation: 2012).

\section{Sampling the words for the items}

The items in the test need to represent the various frequency levels of the language without a bias towards any particular frequency levels. The frequency levels are based on word families which occurred in the British National Corpus according to Bauer and Nations (1993 as cited in Nation 2012). Only a small number of items can be sampled from each vocabulary level, i.e. 10 items per level. It is expected that the scores will decrease by the levels and the total score for the test is what matters. The words listed in the Academic Word List and General Service List will also be used as samples.

2. Making the Stem

The test uses a stem plus a 4 choice in multiple-choice format. The item stem consists of the word followed by a very simple non-defining sentence containing the word. The non-defining sentence has the roles of (1) indicating the part of speech of the word, (2) limiting the meaning of the word where words may have a homograph or very different senses, and (3) slightly cueing the meaning by presenting an example of use. The words represented by distracters should fit sensibly within the stem.

3. Writing the choices

The distracters are the same part of speech as the correct answer, and in most cases the distracters are the meanings of words from around the same 1,000 word frequency level as the correct answer. The choices must be written in a much easier language than the tested word.

4. The Order of the items in the Test

The test items in the test are usually arranged in frequency order. It means that the high-frequency words are arranged in the first half of the test and the low-frequency words are arranged in the last half of the test. This order results in students giving up at later levels. It would be better to mix the levels, with higher frequency words appearing through the whole test, which will likely result in the students' maintained engagement with the test.

5. Piloting

Piloting the test can be done by getting applied linguists who are native speakers of English to individually read and critique the test, replacing the target word with the nonsense word and getting a test-wise native speaker to try to choose the correct answer, and running the tests through the Range program to check the frequency levels of words used in the contexts and choices.

The test items then must be tested for the validity, reliability and practicability. Since this research is only a preliminary research, the procedures must be followed up in the future research.

\section{CONCLUSIONS AND RECOMMENDATION}

This section will discuss the conclusions of the research results on 
vocabulary size test and offer some suggestions and recommendations to follow up this preliminary research. The discussions will be presented according to the order of the research questions.

First, useful words to enable the ELESP students to function effectively in academic contexts were (1) high-frequency words containing 2,000 word families made up of 169 function words and 1831 content words, (2) academic words which are used in the specialized area containing at least 570 word families called the Academic Word List (Coxhead:2000), (3) technical words which deal with linguistics, literature and education which range up to 5,000 word families, (4) lowfrequency words in order to understand conversations, to read newspapers and understand academic texts.

Second, the result of the administration of Nation's Vocabulary Size Test shows that the students' scores range between 33 and 96 words, with the mean score of 66 and median of 65 and mode of 58. It means that students' vocabulary size ranges between 3,300 and 9,600 word families. The average students' vocabulary size was 6,600 word families, which implies that most ELESP students are lexically ready to read texts containing $88.7 \%$ word coverage.

Third, the average students of PBI are familiar with the 6,600 word families which represent high-frequency words in the English language, students are encouraged to acquire more technical words related to linguistics, literature and education. Currently, they are in their mid-frequency level, with the vocabulary size ranging from 3,000 to 9,000 word families. In order to increase their vocabulary size by 10,000 , they need to learn words deliberately and widely on technical words and lowfrequency words of a specialized subject area.

Fourth, using Nation's specifications for making the test, the researcher listed some procedures of test design (Nation: 2012). They are: Sampling the words for the items, Making the Stem, Writing the choices, The Order of the items in the Test, Piloting, Administering the Test.
Based on the conclusions, there are some recommendations addressed to the following stakeholders:

1) Teachers of English as a Foreign Language at university level. It is recommended that the design of the materials, the material revision, and the teaching strategies be adjusted to the students' vocabulary size. The materials should provide meaningful input to increase students' current vocabulary size and the teaching strategies help increase the vocabulary size.

2) Curriculum designers in university level. It is recommended that the curriculum be designed based on the students' vocabulary size. It is urgent that the institution decide what vocabulary size the students in each level should learn in order to improve the quality of the graduates. Vocabulary size test should also be administered regularly to monitor students' independent vocabulary learning. This in turn will increase students' written and spoken performance.

3) Material designers. It is recommended that materials be graded according to the vocabulary levels of the students. Carefully and research-based graded materials will benefit the students and improve the effectiveness of teaching and learning process.

4) Students of the ELESP. It is recommended that students improve their vocabulary size by learning independently and reading extensively many types of text genres.

5) Test Designers. Using the result of this research, test designers are recommended to follow up the procedures and design the Customized Vocabulary Size Test for the ELESP students.

6) Future Research. The results of this research can be used as the reference for future research.

Hopefully, this research can shed some lights on the issues of vocabulary testing to promote effective English language teaching and learning. Research-based decisions will be more recommended to make any alterations on students' behalf. 


\section{REFERENCES}

Anderson, R.C., \& P. Freebody. (1983). Reading comprehension and the assessment and acquisition of word knowledge. In B. Houston (ed.), Advances in Reading/Language Research. Volume 2 (pp. 231-256). Greenwich, CT:JAI Press.

Aziez, Furqanul. (2011). Examining the Vocabulary Levels of Indonesia's English National Examination Texts. Asian EFL Journal, Professional Teaching Articles, Vol. 51, April 2011.

Cervatiuc, Andreea. (2008). ESL Vocabulary acquisition: Target and Approach. In the Internet TESL Journal, Vol. XIV, No. 1, January 2008. Available from http://iteslj.org/Articles/CervatiucVocabularyAcquisition.html.

Coombe, Christine. Assessing vocabulary in the language classroom. In Malaysian English Language Teaching Association, pp. 111- 124.

Coxhead, A., (2010). Grabbed early by vocabulary: Nation's ongoing contributions to vocabulary and reading in a foreign language. In Reading in a Foreign Language, April 2010, Vol. 22, No. 1, pp. $1-14$.

Francis, N., \& H. Kucera. (1982). Frequency analysis of English Usage. Boston: Houghton Mifflin Company.

Hanson, S., \& Padua, Jennifer F. M. (2011). Teaching Vocabulary Explicitly. Honolulu: Pacific Resources for Education and Learning (PREL).

Hirsch, D., \& Nation, P. (1992). What vocabulary size is needed to read unsimplified texts for pleasure? In Reading in a foreign language, Vol. 8 (2), 1992.

Huang, Jianbin., Yuedong, Sheng., \& Ying, Xu. (2007). On the vocabulary size for Chinese English learners. In Polyglossia, Vol. 13, October 2007.

Meara, P. (1996). The vocabulary knowledge framework. In Lognostics.

Meara, P., \& Alcoy, J. C. O. (2010). Words as species: an alternative approach to estimating productive vocabulary size. In Reading in a foreign Language, April 2010, Vol. 22, No. 1, pp. 222-236.

Nagy, W.E., \& Scott, J. A. (2000). Vocabulary processes. In M. L. Kamil, P.B. Mosenthal, P.D. Pearson. R. Barr (Eds.) Handbook of reading research: volume III (pp. 269-284). Mahwah, NJ: Erlbaum.

Nation, I.S.P. \& Beglar, D. (2007) A vocabulary size test. The Language Teacher, 31(7), 9-13.Nation, I. S. P. (1990). Teaching and Learning vocabulary. New York: Newbury House.

Nation, I. S. P. (1995-1996). Best Practice in vocabulary teaching and learning. EA Journal, 3 (2), 7-15.

Nation, P., \& Waring, R. (1997). Vocabulary size, text coverage and word lists. In N. Schmitt \& M. McCarthy (Eds.), Vocabulary: Description, acquisition and pedagogy. Cambridge: Cambridge University Press, pp. 6-19.

Nation, I.S.P. (2001). Learning vocabulary in another language. Cambridge: Cambridge University Press.

Nation, I., \& Heatley, A. (2002). Range: A program for the analysis of vocabulary in texts [Computer Software]. Available from http://www.vuw.ac.nz/lals/staff/paul-nation/nation.aspx

Natin, I. S. P., \& Beglar, D. (2007). A vocabulary size test. In The Language Teacher, 31(7), 9-13.

Nation, I. S. P. (2008). Teaching Vocabulary: Strategies and Techniques. Boston: Heinle Cengage Learning.

Nurweni, A., \& Read, J. (1999). The English vocabulary knowledge of Indonesian university students. English for Specific Purposes, 18, 161-175. 
Pikulski, John J., \& Templeton, S. (2004). Teaching and Developing Vocabulary: Key to Long-Term Reading Success. Houghton Mifflin Company. Retrieved January 9, 2013, from http://www.eduplace.com/state/pdf/author/pik_temp.pdf.

Read, John. (2007). Second Language Vocabulary Assessment: Current Practices and New Directions. International Journal of English Studies. Vol. 7 (2), 2007, pp. 105-125. www.um.es/ijes.

Read, J. (2000). Assessing vocabulary. Cambridge: Cambridge University Press.

Schmitt, N., \& Meara, P. (1997). Researching vocabulary through a word knowledge framework: Word associations and verbal suffixes. In SSLA, Vol. 20, pp. 17-36. Cambridge University Press.

Schmitt N., \& McCarthy, M. (1997). Vocabulary, description, acquisition and pedagogy. Cambridge: Cambridge University Press.

Schmitt, N. (2000). Vocabulary in language teaching, Cambridge: Cambridge University Press.

Schmitt, N. (2008). Teaching vocabulary. Pearson Education, Inc.

Scott, Judith. A., Hoover, Merrit., Flinspach, Susan Leigh., \& Vevea, Jack L. (n.d.) A multiple-level vocabulary assessment tool: measuring word knowledge based on grade-level materials. In National Reading Conference Yearbook, No. 57, pp. 325-340.

Thorndike, E., \& Lorge, I. (1944). The Teachers' Word Book of 30,000 Words. Columbia: Teachers College.

Watts, J. Measuring the effectiveness of a vocabulary programme. Pp. 15-25.

Xing, P., \& Fulcher, G. (2006). Reliability Assessment for Two Versions of Vocabulary Levels Tests. www.sciencedirect.com.

Internet vocabulary testing websites

http://www.lextutor.ca/

http://my.vocabulary.com

http://www.victoria.ac.nz/lals/staff/paul-nation.aspxhttp://jalt-

publications.org/tlt/resources/2007/0707a.pdf 